1988

日本機械学会論文集 $(\mathrm{C}$ 編 $)$

76 巻 768 号 $\left(2010^{-} 8\right)$

論文 No.09-0782

\title{
異種材料同径二球の向心直衝突*
}

\author{
感本広 文*1, 羽川 達 哉*2, 河 村庄 造*1
}

\section{Direct Central Impact between Two Spheres Made of Dissimilar Materials}

\author{
Hirofumi MINAMOTO*3, Tatsuya HAGAWA and Shozo KAWAMURA \\ *3 Department of Mechanical Engineering, Toyohashi University of Technology, \\ 1-1 Hibarigaoka,Tempaku-cho, Toyohashi-shi, Aichi, 441-8580 Japan
}

\begin{abstract}
The impacts between structural elements are often happened in engineering applications. There are many types of impacts in such situations. Among them, direct central impacts between two spheres are one of the most basic impact configurations. So far, several expressions for the coefficient of restitution have been proposed by K. L. Johnson, W. J. Stronge, C. Thornton, but they mainly focused on the impacts between two spheres made of same materials. This paper investigates the influence of material dissimilarity on the impact properties in detail. The experiments between spheres made of aluminum and steel were conducted. Then the numerical simulations have been carried out by using Finite Element Method. The results were compared between the experiments and simulations and they agreed well. In the present study, the deformation concentrated on the aluminum sphere. Further, the profile of the contact surface became concave. For the impact between spheres made of dissimilar materials, the concept of composite coefficient of restitution has been successfully applied to several experimental results so far. According to the composite coefficient, the coefficient of restitution for the dissimilar materials should take the intermediate value between those for the same materials. However, the coefficient of restitution for the dissimilar impact was lower than those of the same materials in the present study. It is thought that this discrepancy is caused from the assumption of flat contact surface in the composite coefficient of restitution, while it was concave as seen in the results of this paper.
\end{abstract}

Key Words: Contact Problem, Inelasticity, Computational Mechanics, Direct Central Impact, Spheres, Coefficient of Restitution, Machine Dynamics

\section{1. 緒言}

一般に, 稼働中の機械や構造物には, 構成要素の運 動に伴って各部に動的な接触や衝突を生じる事が考 えられる. 衝突を伴う構造や機械要素には種々の形状 ならびに材料が考えられるが, 最も基本的な衝突形態 の一つとして球の向心直衝突が挙げられる.これに関 しては従来から多くの研究が行われている.しかしな がら，そのほとんどは，同じ材料でできた二球の衝突 に関するものであり，二球の材料が異なる場合の衝突 特性についての研究は少なく，その衝突特性が十分明 らかになっているとは言い難い.

同じ材料でできた同径二球の衝突特性については, これまでに実験ならびに数值シミュレーションによ っ, 弹性体 ${ }^{(1)-(8)}$, 弾塑性体 ${ }^{(9)}$ (15)等の衝突特性が検討

\footnotetext{
* 原稿受付 2009 年 9 月 3 日.

*1 正員, 豊橋技術科学大学工学部 (亚 441-8580 豊橋市天伯町 字雲情方 1 -1).

*2 学生員, 豊橋技術科学大学大学院.

E-mail : minamoto@me.tut.ac.jp
}

されている.一方，材質の異なる二球の衝突について

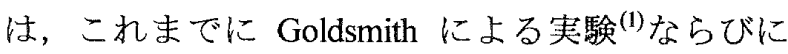
Hodgkinson による複合反発係数 (Composite Coefficient of restitution) ${ }^{(16)}$ に関する研究などが行われている. また，複合反発係数については，近年，Coaplen と Stronge によってエネルギ保存に基づく修正がなされ， 物理的な合理性が高められている(17).しかしながら， 実験結果との一致は十分とはいえず，その原因は明ら かにされていない.

そこで，本論文で性材質の異なる同径二球の衝 突について，実験ならびに有限要素法による数值 シミュレーションを行う。そして，二球の材料特 性の相違が反発倸数, 衝突時間等の衝突特性およ び，各球に作用する接触力，球の変形等に及ぼす 影響について考察する。さらに, Johnson K.L. ${ }^{(9)}$, Stronge W.J. ${ }^{(1)}$, Thornton C. ${ }^{(10)}$ による二球の反発 係数の理論式ならびにJ.Coaplen ${ }^{(17)}$ による複合反発 係数と本論文の結果を比較し，従来理論による誤 差の原因について検討する。 


\section{2. 衝突実験}

実験には直径 1 インチのアルミニウム球(A5052: JIS-H-4040) と軸受用鋼球（SUJ2: JIS G 4805)を用いた. 製造過程における残留応力の影響を取り除くため，実 験前に不活性ガス中で完全焼きなましを行った (A5052 球は $350^{\circ} \mathrm{C}$, SUJ2 球は $800^{\circ} \mathrm{C}$ ) . 図 1 亿電気 油圧サーボ式材料試験機ならびにスプリットホプキ ンソン棒法によって求めた各材料の真応力一真ひず み線図を示声。また，表 1 に各材料の基本的な材料特 性老示守。

図 2に示す振り子によって二球を衝突させる ${ }^{(15)}$.

Table 1 Material properties of SUJ2 and A5052

\begin{tabular}{|c|c|c|c|c|}
\hline & $\begin{array}{c}\text { Young's } \\
\text { modulus } \\
E(\mathrm{GPa})\end{array}$ & $\begin{array}{c}\text { Yield } \\
\text { stress } \\
\sigma_{y}(\mathrm{MPa})\end{array}$ & $\begin{array}{c}\text { Poisson's } \\
\text { ratio } \\
\nu\end{array}$ & $\begin{array}{c}\text { Density } \\
\rho \\
\left(\mathrm{kg} / \mathrm{m}^{3}\right)\end{array}$ \\
\hline SUJ2 & 206 & 350 & 0.3 & 7825 \\
\hline A5052 & 73.5 & 90.4 & 0.33 & 2640 \\
\hline
\end{tabular}

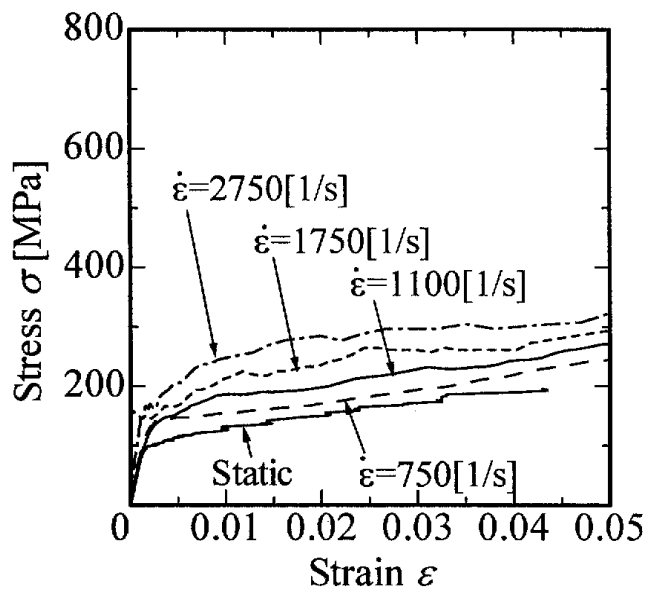

(a) $\mathrm{A} 5052$
球は天板の所定位置にケブラー繊維製紡績系で吊 した. 一方の球（被衝突球）を静止させ，もう一方の 球 (衝突球) 学所定の角度から解放して静止球に衝突 させる．衝突球の振上げ角 $\theta_{0}$ を変えることによって 衝突速度を変化させる. 振り子の腕の長さは $50 \mathrm{~cm}$ と したので衝突速度は $3 \mathrm{~m} / \mathrm{s}$ で設定可能である．実験の 様子を正面からデジタルビデオカメラ (30 flames/sec) で録画し，衝突前後の球の角度を読み取った。

球に作用する空気抵抗は小さいとして無視すると， 衝突前後のエネルギー保存より, 反発係数は次式で求 められる。

$$
e=\frac{\sqrt{1-\cos \theta_{2}}-\sqrt{1-\cos \theta_{1}}}{\sqrt{1-\cos \theta_{0}}}
$$

ここで， $\theta_{0}$ は衝突前の衝突球の角度， $\theta_{1} ， \theta_{2}$ はそ れぞれ, 衝突球, 被衝突球の衝突後の最大振れ角であ る.

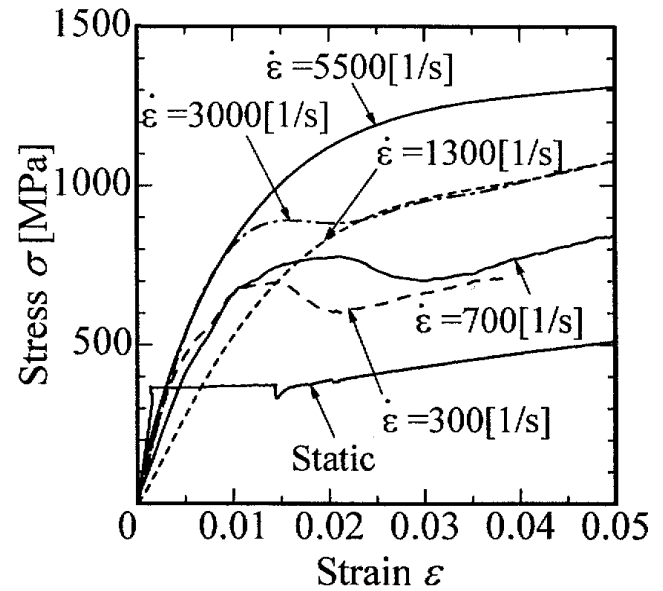

(b) SUJ2

Fig.1 Stress-strain curves

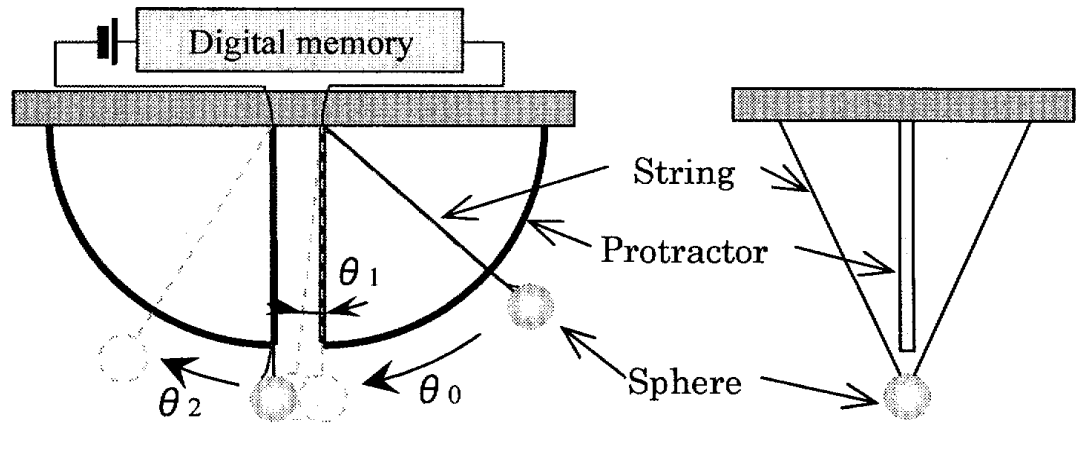

(a) Front view

(b) Side view

Fig.2 Schematic experimental setup 
各球には導線を取り付け, 導線は電源とディジタル メモリに接続されている.球の接触中に観測されるデ イジタルメモリの通電時間を接触時間として測定し た。

\section{3. 有限要素法による衝突シミュレ一ション}

衝突解析には汎用動的非線形有限要素解析ソフト LS-DYNA v970 ${ }^{(18),(19)}$ 使用した。実験で得られた接触 縁の形状はほぼ円形であった，よって，球の環状变形 モードの影響はきわめて小さいと考えられる.そこで, 本論文では二球の衝突を球の中心軸に関する軸対称 問題として取り扱う。要素には四節点軸対称要素（回 転対称体のモデル化に用いられる環状要素）を用いた。 二球の中心軸を含む任意断面におうけるメッシュ分割お よび接触部近傍の搪大図を図 3 に示す，接触部は衝突 時に局所的な変形を生じるため細かい要素分割とし， 接触部から離れるにつれて順次要素サイズを大きく した. 実験条件と同梂に, 一方の球に初速度を与えて, 静止球に衝突させるシミュレーションを行った.

材料モデルには, Model 24 (Piecewise Linear Isotropic Plasticity） ${ }^{(19)}$ を用い，表 1 の各值ならびに図 1 の応力 一ひずみ関係を多直線近似で入力した。

構成関係には次式が採用されている(19)。

$$
s_{i j}^{\nabla}=2 G \dot{\varepsilon}_{i j}^{\prime}
$$

ここで， $s_{i j}^{\nabla}$ は偏差応力の Jaumann 速度， $\dot{\varepsilon}_{i j}^{\prime}$ は偏差ひ

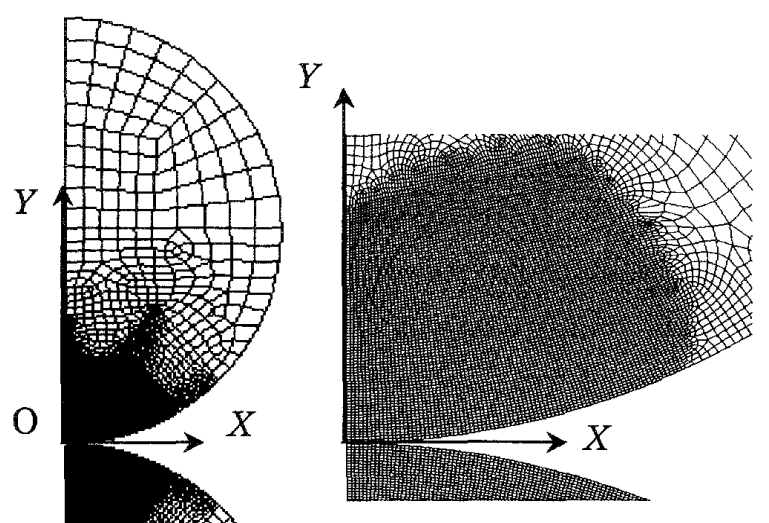

(b) Fine meshed area
ずみ速度，G は横弾性係数である.降伏判定にはミー ゼスの降伏条件を使用した。降伏関数 $\phi$ は, 次式で表 わされる。

$$
\phi=\frac{1}{2} s_{i j} s_{i j}-\frac{1}{3} \sigma_{y}^{2}
$$

接触計算にはペナルティ法を使用した. ただし，接 触面における摩擦の影響は小さいものとして無視し ている.

なお，本論文の衝突速度の範囲では，球の変形は接 触点近傍に集中しており，その他の部分（Fig.3(a)でメ ッシュ分割が粗い部分）は剛体運動とみなせることを 確認している. よって, 反発係数 $e$ は球中心の節点速 度によって次式で求めた。

$$
e=-\frac{V_{1}-V_{2}}{V_{10}}
$$

ここで， $V_{10}$ は衝突球の初速度（二衝突速度 $V i$ ) であ り， $V_{1}, V_{2}$ はそれぞれ衝突球，被衝乫球の衝乫終了後 の球中心の節点速度である.

\section{4. 結果と考察}

本章では，はじめに 2 章及び 3 章で述べた実験と有 限要素解析による結果を比較し, 数値シミュレーショ ンの妥当性を確認する。また，同種材料の同径二球衝 突の場合との比較を通じて異種材料同径二球の衝突 特性について考察する. 最後に，既に提案されている 反発係数の理論式および複合反発係数による值を本 論文の結果と比較し, 既存式に生じる誤差の原因につ いて検討する。

$4 \cdot 1$ 実験ならびにシミュレーション結果 図 4 にAluminum-Steel 同径二球の衝突実験ならびに有限 要素シミュレーションによって得られた反発係数と 衝突速度の関係を示す。同様に衝突時間と衝突速度の 関係を図 5 に示寸。図中の黑丸プロットは実験結果, 実線はシミュレーションによる結果である. 実験結果 のプロットは 3 回の実験の平均值である.これらの図 より,シミュレーション結果は実験結果を良好にシミ ニレートできていることが確認できる.

$4 \cdot 2$ 同種材料同径二球の衝突との比較 2 章, 3 章と同様の方法で同種材料同径二球（A5052 同士, SUJ2 同士) の衝突実験ならびに有限要素シミュレー ションを行い，異種材料（A5052-SUJ2）同径一球に よる結果と比較する.

図 6 に反発係数と衝突速度の関係, 図 7 に衝突時間 と衝突速度の関係を示す.これらの図より同種材料二 球の衝突に対しても，FEM によるシミュレーション 結果は実験結果を良好にシミュレートできているこ とが確認できる，そして異種材料二球（A5052-SUJ2）

Fig.3 Finite element subdivision 
の反発係数は，各同種材料球（SUJ2 同士，A5052 同 士）の反発係数を下回っていることが分かる．また， 接触時間はA5052-SUJ2，A5052 同士，SUJ2 同士の順 に長く, 異種材料二球の衝突時間は各同種材料球より

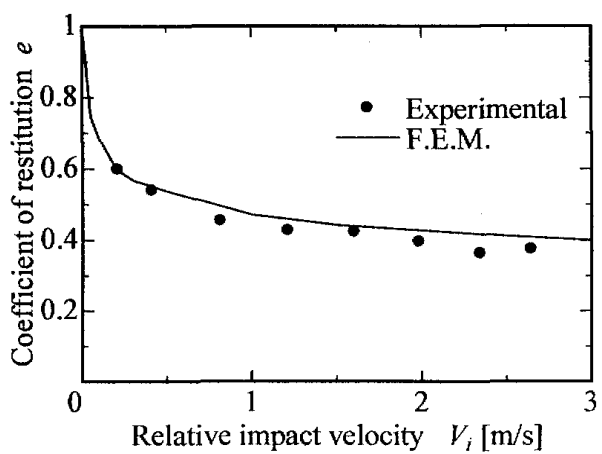

Fig.4 Coefficient of restitution (A5052-SUJ2)

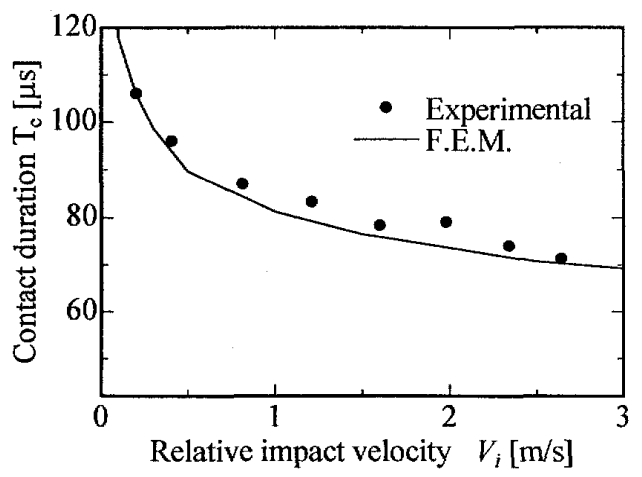

Fig.5 Contact duration (A5052-SUJ2)

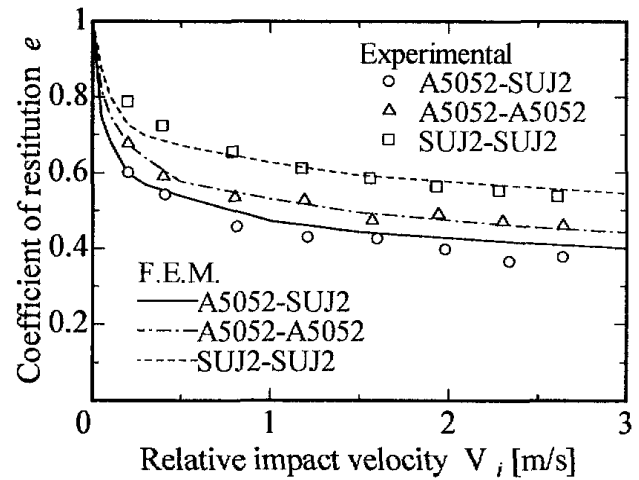

Fig.6 Comparison of the coefficient of restitution

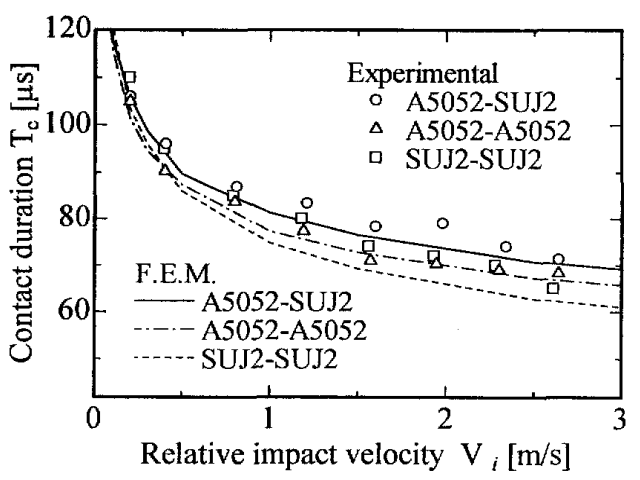

Fig.7 Comparison of the contact duration
長くなっている事が分かる. 以下ではシミュレーショ ン結果によって詳細な考察を行う。

図 8 は衝突速度と球の圧縮変形量 $\delta$ (Y 軸に沿う球 直径の収縮量）の関係，図 9 は衝突速度と接触门直径 $a$ の関係を示す. 各衝突速度における球の圧縮変形量 を見ると, 同種材料では SUJ2 同士に比べて A5052 同 士の方が大きい.A5052-SUJ2 の場合は SUJ2 の変形が 非常に小さく，ほとんどが A5052 の変形になってい ることが分かる。そして，A5052-SUJ2 の衝突におけ る A5052 の変形量は, A5052 球同士の場合に比べて 非常に大きくなっている事が分かる.また接触円直径 についても，各衝突速度におうて A5052-SUJ2，A5052 同士，SUJ2 同士の順で大きくなっている.ここでは 球の圧縮変形量と接触円直径をみたが，4.3 節で接触 部の詳細な変形形状を示す，なお，図 9 の一部で接触 円直径が不連続的に增加しているのは有限要素メッ シュ分割の影響によるものであると思われる。

図 10，11 はそれぞれ $V_{i}=1 \mathrm{~m} / \mathrm{s}$ の場合に対する，接 触力ならびに球 $の$ 圧縮変形量の時間的変化を示す. 時 間軸の原点は接触開始時である．図 10 より，SUJ2 同 士の接触力が最も大きく，A5052-SUJ2 は A5052 同士 の場合よりやや高くなっている. 図 11 より球の圧縮 変形は, 衝突中においても衝突後の残留変形量 (図 8) と同じ大小関係である事が分かる．A5052-SUJ2 の衝

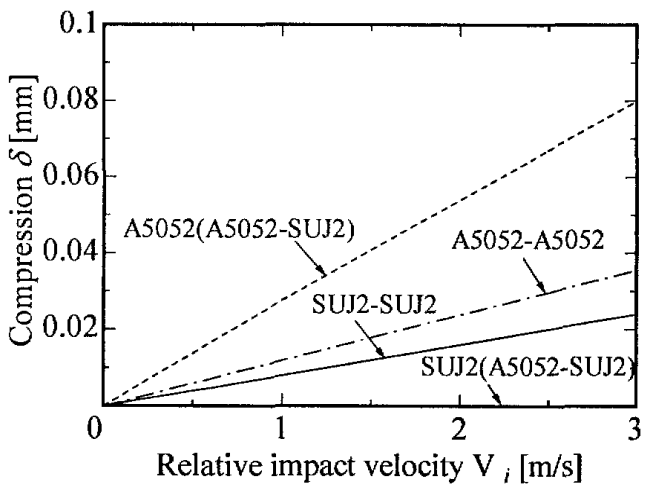

Fig.8 Compression of spheres

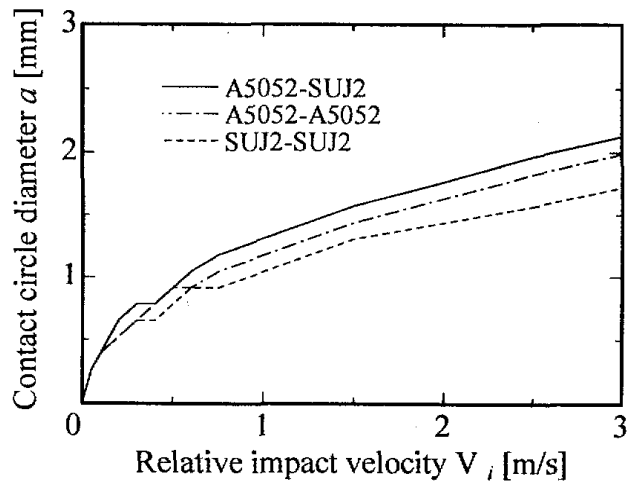

Fig.9 Size of contact circle 


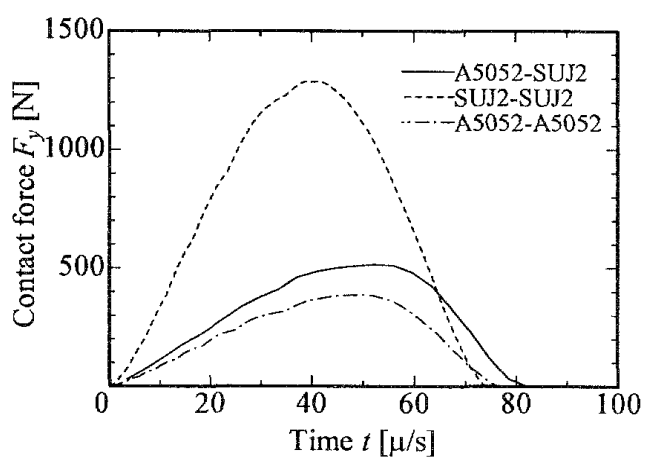

Fig.10 Variation of contact force with time

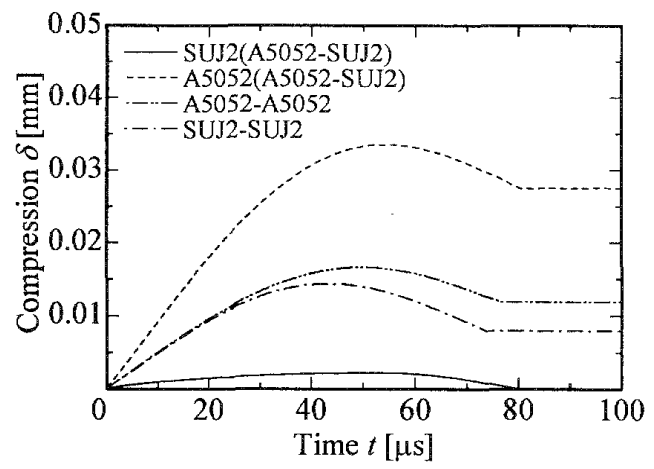

Fig11 Variation of sphere compression with time

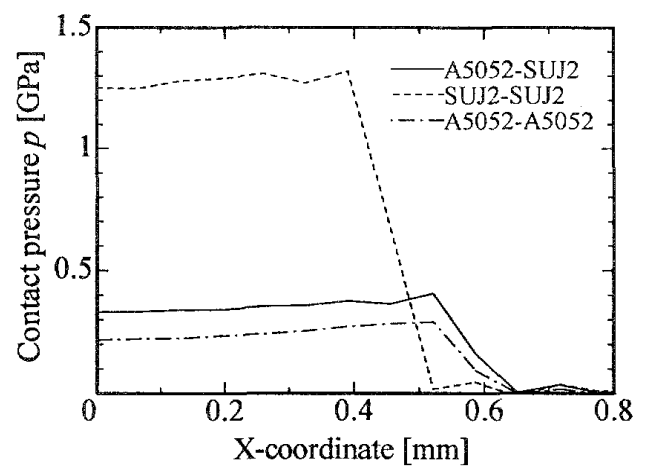

Fig.12 Contact pressure distribution

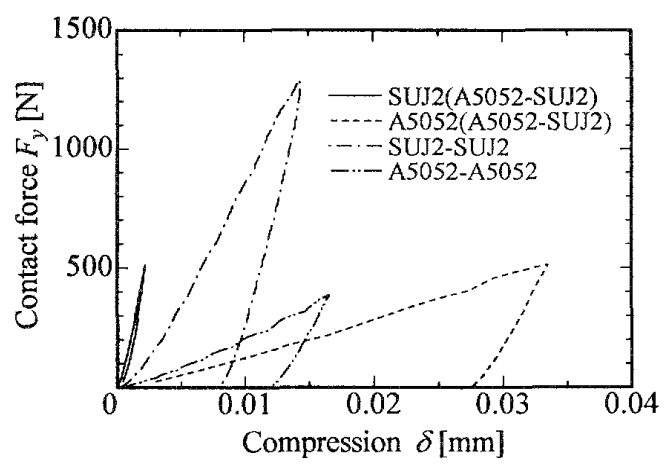

Fig. 13 Contact force-compression diagram
突において，衝突後の SUJ2 球の変形量はほぼ 0 とな っており,A5052 球にのみ永久変形が残っている事が 分加 (図 11).

図 12 は図 10 の最大接触力時における接触圧力の 分布を示している. SUJ2 同士の接触圧力が最も高く， A5052-SUJ2 はA5052 同士の場合よりやや高くなって いる.これは，SUJ2 球同士の場合は，材料のひずみ 速度依存性の影響が影著に現れる ${ }^{(15)}$ のに対し， A5052-SUJ2 の場合は前述のように SUJ2 がほとんど 弾性衝突であるため, SUJ2 のひずみ速度依存性の影 響が現れなかったものと考えられる。

図 13 は図 10 , 図 11 から時閒を消去して求めた球 の接触力と圧縮変形量の関係を示す，圧縮段階におけ る線図の公配 (風性) を見ると, A5052-SUJ2 におけ る A5052 球の剛性が最も低くなっていることが分か る。また，A5052-SUJ2 における SUJ2 球の剛性が最も 高く，ほぼ弾性衝突であることが確認できる.

反発係数は衝突中の工ネルギー損失（二塑性変形に よる仕事) の程度を表す，衝突中に球になされた仕事 は図 13 の横軸と力一変位線図で囲まれる面積に等し い。図 13 より，A5052 球同士の衝突に比べて A5052-SUJ2 の場合は仕事量が大きくなっている.した がって, A5052 球同士の衝突に比べて A5052-SUJ2 の 場合の反発係数が低くなった主な原因はアルミ球の変 形が増加したことによると考えられる.

$4 \cdot 3$ 球の応力・ひずみ・変形 図 14, 図 15 は それぞれ A5052-SUJ2， $V_{i}=3 \mathrm{~m} / \mathrm{s}$ の場合の，最大圧縮時 における球接触部付近のミ一ゼスの相当応力分布, お よび，残留相当塑性ひずみ分布である。

同種材料球の場合, 応力分布は接触面に関して対称 となるが, 図 14 ではアルミ球内部でより広い範囲に 㐫力が分布していることが分かる。また，同種材料球 同士の場合と比較したところ, 図中の SUJ2 球の応力 は, SUJ2 球同士の場合に比べて低く，同様に A5052 球は A5052 球同士の場合に比べて高い応力を生じて いることが分かった.

図 15 より，塑性ひずみは A5052 球にの夕生じてい ることが分かる.また，それは接触中心付近の表面よ りもむしろ接触縁および球の内部で大きくなってい る，そしてその值は A5052 球同士の場合の 2 倍程度 であった。

図 16 に衝突後の接触領域付近の形状を示す。ここ では変形形状において $V_{i}=3 \mathrm{~m} / \mathrm{s}$ と同様の傾向を示し， その差異がより明確な $V_{i}=10 \mathrm{~m} / \mathrm{s}$ の場合を示した。 図よ り同種枋料同径二球（A5052 同士，SUJ2 同士）の衝 突では接触面が平坦であるが, A5052-SUJ2 の場合は 


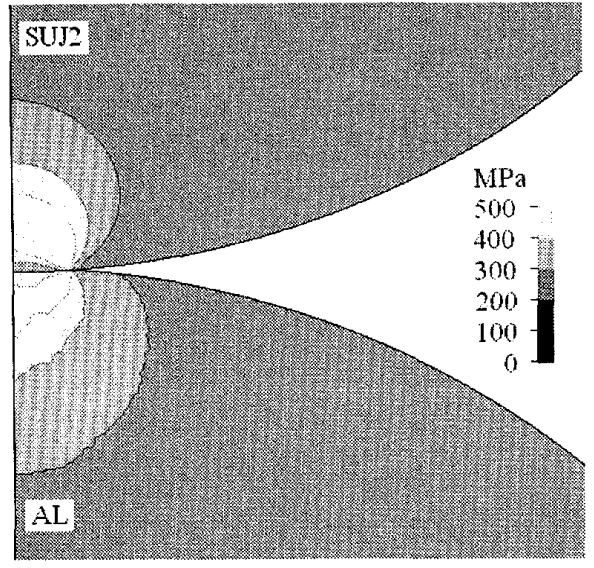

Fig.14 Distribution of Mises stress at maximum compression(A5052-SUJ2, $V_{i}=3 \mathrm{~m} / \mathrm{s}$ )

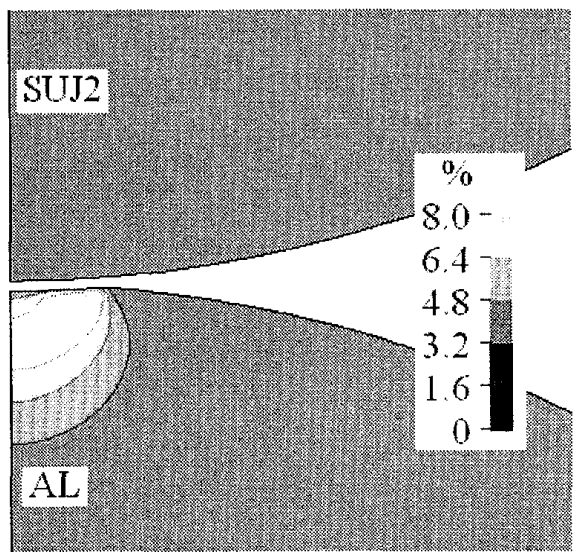

Fig.15 Distribution of residual effective plastic strain(A5052-SUJ2, $\left.\quad V_{i}=3 \mathrm{~m} / \mathrm{s}\right)$
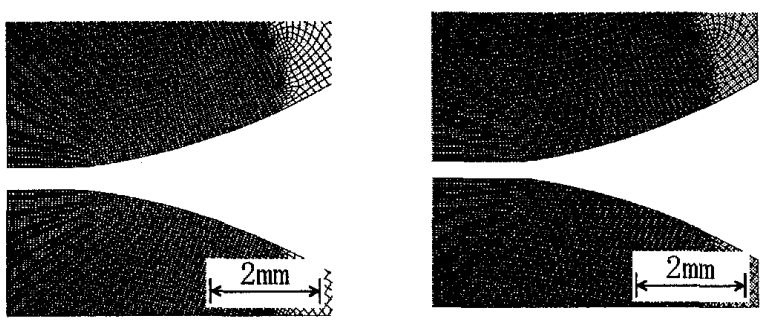

(a) SUJ2-SUJ2

(b) A5052-A5052

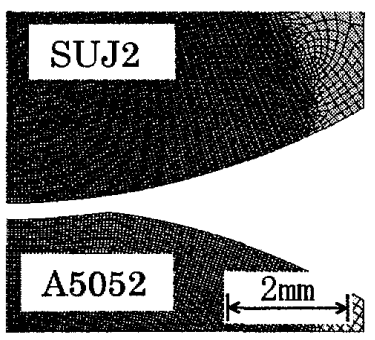

(c) A5052-SUJ2

SUJ2 はほとんど元の球面を維持し，A5052 に球面状 の残留圧痕を生じている事が分かる.

4.4 反発係数 これまでに提案されている主な 反発係数の理論式として，以下の 3 つが挙げられる.

(1) K.L. Johnson ${ }^{(9)}$

$e^{2}=\frac{3 \sqrt{2} \pi^{5 / 4}}{5}\left(\frac{p_{y}}{E^{*}}\right)\left(\frac{\frac{1}{2} m^{*} V_{i}^{2}}{p_{y} R^{3}}\right)^{-1 / 4}$

ここで, $p_{y}=3 \sigma_{y}$ であり， $\sigma_{y}$ は軟らかい方の材料の降 伏応力である.

(2) W.J. Stronge ${ }^{(11)}$

$$
e^{2}=\left(\frac{V_{y}}{V_{i}}\right)^{2}\left[\frac{8}{5}\left(\frac{V_{i}}{V_{y}}\right)^{2}-\frac{3}{5}\right]^{3 / 4}
$$

ここで, $V_{y}^{2}=\frac{4 \pi}{5}\left(\frac{3 \pi}{4}\right)^{4}\left(\frac{p_{y}}{E_{*}}\right)^{4} \frac{p_{y} R_{*}^{3}}{m_{*}^{*}}$,

$p_{y}=1.1 \sigma_{y} \sim 2.8 \sigma_{y}$.

(3) C. Thornton ${ }^{(10)}$

$$
\begin{aligned}
e & =\left(\frac{6 \sqrt{3}}{5}\right)^{1 / 2}\left[1-\frac{1}{6}\left(\frac{V_{y}}{V_{i}}\right)^{2}\right]^{1 / 2} \\
& \times\left[\frac{V_{y} / V_{i}}{V_{y} / V_{i}+2 \sqrt{6 / 5-(1 / 5)\left(V_{y} / V_{i}\right)^{2}}}\right]^{1 / 4}
\end{aligned}
$$

ここで, $V_{y}=\left(\frac{\pi}{2 E_{*}}\right)^{2}\left(\frac{8 \pi R_{*}^{3} p_{y}^{5}}{15 m_{*}}\right)^{1 / 2}$

$p_{y}=1.6 \sigma_{y} \sim 2.8 \sigma_{y}$

$\frac{1}{E_{*}}=\frac{1-v_{1}^{2}}{E_{1}}+\frac{1-v_{2}^{2}}{E_{2}}, \frac{1}{R_{*}}=\frac{1}{R_{1}}+\frac{1}{R_{2}}$,

$\frac{1}{m_{*}}=\frac{1}{m_{1}}+\frac{1}{m_{2}}$

また, 材質の異なる二球の衝突における反発倸数の 算出方法として, 複合反発係数 (Composite coefficient of restitution）が提案されている ${ }^{(16)}$.これは, 同種材料 球同士の反発係数 $e_{1}, e_{2}$ を用いて，材質の異なる二球 の反発倸数 $e$ を求めようとするものである. 近年, こ れにエネルギー保存則を考慮したエネルギー複合反 発係数 (Energetic composite coefficient of restitution) J.Coaplenによって提案されている.

Fig.16 Sphere shape after impact $\left(V_{i}=10 \mathrm{~m} / \mathrm{s}\right)$ 
(4) エネルギ一複合反発係数 $\left(^{(17)}\right.$

$$
e^{2}=-\frac{W_{r}}{W_{c}}=\frac{W_{1 c} e_{1}^{2}+W_{2 c} e_{2}^{2}}{W_{c}}
$$

ここで, $W_{\mathrm{c}}$ は圧縮仕事, $W_{r}$ は反発仕事, $W_{i \mathrm{c}}(i=1,2)$

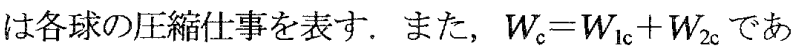
り, 圧縮エネルギーは次式のように各球の岡性 $k_{i}$ の比 で按分される.

$W_{c 1}=\frac{k_{2}}{k_{1}+k_{2}} W_{c}, \quad W_{c 2}=\frac{k_{1}}{k_{1}+k_{2}} W_{c}$

これらの事より，エネルギ一複合反発係数 $\mathrm{e}$ と同種材 料二球の反発係数 $e_{1}, e_{2}$ との間に次の関係が成り立つ. $\min \left(e_{1}, e_{2}\right) \leqq e \leqq \max \left(e_{1}, e_{2}\right)$

本研究では, FEM シミュレーションで得られた結果 から $W_{\mathrm{lc}}, W_{2 \mathrm{c}}$ に対応卞る反発係数 $e_{1}, e_{2}$ を求めた.

岡性 $k_{i}$ はヤング率ならびに降伏強度に基づく決定法 が提案されている。

(4a) ヤング率基準剛性がヤング率に比例すると 考えて， $k_{i}=c E_{i}$ (cは比例定数) と書くと, 式 (8) は 以下のようになる。

$$
e^{2}=\frac{E_{2} e_{1}^{2}+E_{1} e_{2}^{2}}{E_{1}+E_{2}}
$$

（4b）降伏強度基準球が降伏するまでの仕事と等 価な仕事を与える線形剛性は次式で与えられる. $k_{i}=\frac{5}{4} \pi \theta_{y} \sigma_{y i} R_{i}$

これより，式（8）は以下のようになる.

$$
\begin{aligned}
& \quad e^{2}=R * \sigma_{y^{*}}\left(\frac{e_{1}^{2}}{R_{1} \sigma_{y 1}}+\frac{e_{2}^{2}}{R_{2} \sigma_{y 2}}\right) \\
& \text { ここで, } \frac{1}{\sigma_{y^{*}}}=\frac{1}{\sigma_{y 1}}+\frac{1}{\sigma_{y 2}} .
\end{aligned}
$$

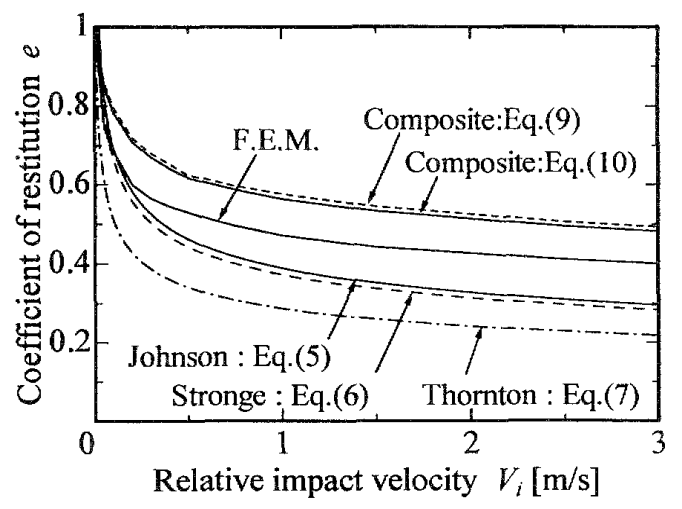

Fig. 17 Comparison of the coefficient of restitution among present result and the predictions
図 17 にFEM によるシミェレーション結果と, 式 $(5),(6),(7),(9),(10) に よ る 反$ 発係数の比較を示す。式 (6),(7)では $p_{y}$ を定める必要があるが，文献(13)による と降伏領域が接触面に達している場合は $p_{y}=2.8 \sigma_{y}$ が 適切で女るとされている.ここでは，図12に示される ように接触在力分布が平坦であることから降伏が接触 表面に達していると判断し， $p_{y}=2.8 \sigma_{y}$ を用いた（弹性 あるい㤏伏初期では，へルツの接触圧力分布に類似 の接触压力分布が現れるものと思われる）。

図 17 より，式(5),(6),(7)による結果はFEM シミュレ ーションの結果を下回っている. そして, 複合反発係 数(9),(10)による結果は FEM シミュレーションの結果 を過大評価していることが分かる．この差は反発係数 式の導出において，図 16(a),(b)のような平坦な接触面 が仮定されているのに対して，実際には図 16(c)のよ うに球面状の変形を生じている(変形仕事算出の䛊差 要因となる) 事が主な原因であると考えられる。また， 式(5),(6),(7)では接触王力 $p_{y}$ に，軟らかい力の材料の 降伏応力を採用しているため, 反発係数が過小評洒さ れたものと考えられる.したがって，A5052-SUJ2 のように材料特性が大きく異なる場合, 従来の反発係 数の理論式では十分な予測精度が得られないと考え られる.

\section{5. 結言}

本論文では材質の異なる同径二球 (A5052 と SUJ2) の衝突について，実験ならびに有限要素法による数值 シミュレーションを行った。実験結果とシミュレーシ ヨン結果は良好な一致を示し,シミュレーション結果 を用いて，材質の異なる二球と同種材料の二球の衝突 特性を比較し, 衝突中の球の挙動を詳細に調べた. そ して，既存の主な反発係数の理論式ならびにエネルギ 一複合反発係数について検討を行った．以下に結果を 列挙する.

-A5052-SUJ2 同径二球の反発係数は, 同種材料球同士 (A5052 同士，SUJ2 同士）と比較して低くなった。

-A5052-SUJ2 同径二球の衝突時間は, 同種材料球同士 より長くなった。

- 同種材料球同士の衝突後の接触面は平面 (円形平面) となるが, A5052-SUJ2 球の衝突ではSUJ2 球はほほ弾 性衝突となり，A5052 球に球面状の衝突痕が生じた。

・既存の反発係数の理論式は，二球の材料特性が大き く異なる場合において，十分な精度が得られなかった。

材料が異なる二球の反発係数を精確に予測するため には，材料の風性差による接触面形状の変化を考慮す る必要があると考えられる。 


\section{文献}

(1) Goldsmith, W., Impact, (1960),Chap.6, Edward Arnold.

(2) JSME Mechanical Engineers's Handbook, Series $\alpha$ (2007), pp.2-32, The Japan Society of Mechanical Engineers (in Japanese).

(3) Love A. E., A Treatise on the Mathematical Theory of Elasticity, Forth edition, (1934), pp. 198-200, Cambridge University Press.

(4) Timoshenko, S. and Goodier, N., Theory of Elasticity, 3rd edition, (1970), p. 420, McGraw-Hill, New York.

(5) Tatara, Y. and Moriwaki, N., Study on Impact of Equivalent Two Bodies : Coefficients of Restitution of Spheres of Brass, Lead, Glass, Porcelain and Agate, and the Material Properties, Bulletin of Japan Society of Mechanical Engineers, Vol. 25, No. 202 (1982), pp. 631-637.

(6) Villaggio, P., The Rebound of an Elastic Sphere Against a Rigid Wall, Transactions of the ASME, Journal of Applied Mechanics, Vol. 63, (1996), pp. 259-263.

(7) Schiehlen, W. and Seifried, R., Three Approaches for Elastodynamics Contact in Multibody Systems, Multibody System Dynamics, Vol. 12, (2004), pp.1-16.

(8) Tatara, Y., Extensive Theory of Force-Approach Relations of Elastic Spheres in Compression and in Impact, Transactions of the ASME, Journal of Engineering Materials and Technology, Vol. 111, (1989), pp.163-168.

(9) Johnson K. L., Contact Mechanics, (1985), Chap.11, Cambridge University Press.

(10) Thornton, C., Coefficient of Restitution for Collinear Collisions of Elastic-Perfectly Plastic Spheres,
Transactions of the ASME, Journal of Applied Mechanics, Vol. 64, (1997), pp. 383-386.

(11) Stronge, W. J., Impact Mecahnics, (2000), Chap. 6, Cambridge University Press.

(12) Vu-Quoc L., Zhang X. and Lesburg L., A Normal Force-Displacement Model for Contacting Spheres Accounting for Plastic Deformation; Force-Driven Formulation, Transactions of the ASME, Journal of Applied Mechanics, Vol. 67, (2000), pp. 363-371.

(13) Chuan-Yu Wu, Long-Yuan Li and Colin Thornton, Rebound Behaviour of Spheres for Plastic Impacts, International Journal of Impact Engineering, No. 28 (2003), pp. 929-946.

(14) Chuan-Yu Wu, Long-Yuan Li and Colin Thornton, Energy Dissipation during Normal Impact of Elastic and Elastic-plastic Spheres, International Journal of Impact Engineering, Vol. 32, (2005), pp. 593-604.

(15) Minamoto H. and Kawamura S., Effects of material strain rate sensitivity in low speed impact between two identical spheres, International Journal of Impact Engineering, Vol. 36, (2009), pp. 680-686.

(16) Hodgkinson E., On the collision of imperfectly elastic bodies, Report of the Fourth Meeting of the British Association for the Advancement of Science,(1835).

(17) Coaplen J., W. J. Stronge and Ravani B., Work equivalent composite coefficient of restitution, International Journal of Impact Engineering, No. 30, (2004), pp. 581-591.

(18) LS-DYNA KEYWORD USER'S MANUAL, Version 970, Livermore Software Technology Corporation, (2003).

(19) LS-DYNA THEORY MANUAL, Livermore Software Technology Corporation, (2006). 